\title{
Role Of Bedside Index For Severity Of Acute Pancreatitis Bisap) Score In Predicting Outcome In Acute Pancreatitis
}

\author{
Akut Pankreatitte Sonucu Tahmin Etmede Akut Pankreatit Bisap Skoru Şiddeti \\ İçin Doktor Tutum Endeksinin Rolü
}

Shahnawaz Bashir bhat, Baint Singh, Hanief Mohamed Dar, Aijaz Ahmad Malyar, Alfar Nafae, Mir Mujtaba Ahmad

Postgraduate department of Surgery, Government Medical Col- lege Srinagar, Jammu \& Kash- mir, India. 190010.

\section{Corresponding Author:}

Hanief Mohamed Dar

\section{Address:}

MBBS, MS, senior resident, GMC, Srinagar, India.

E-mail:

drhaniefms@ghmail.com

\section{Mobile number:}

+919797218889

\section{Received:}

02-01-2015

\section{Accepted:}

17-03-2015

\section{ÖZET}

Amaç: Akut pankreatit sonucu tahmin etmede, akut pankreatit şiddeti (BISAP) skoru için doktor tutum endeksinin rolünü incelemektir.

Yöntem: $\mathrm{Bu}$ tek hastaneye bağlı prospektif çalışma, belirtilerin başlangıcından itibaren 48 saat içerisinde kabul edilen 50 akut pankreatit hastasını içermektedir. Hastalar, kabuldeki BISAP skoruna göre iki gruba ayrılmıştır: BISAP skoru <3 olanlar (hafif akut pankreatit) ve BISAP skoru>3 olanlar (şiddetli akut pankreatit). BİSAP skorunun akut pankreatit hastalar için mortaliteyi, morbiditeyi ve hastanede yatmayı tahmin etmede yeteneği analiz edilmiştir.

Çalıșma Sonuçları: 3'den büyük BİSAP skoru, artan oranda geçici organ yetmezliği gelişimi, daimi organ yetmezliği ve pankreatik nekroz riski ile ilişkilendirilmiştir (istatiksel olarak anlamlı). BISAP $\geq 3$ olan hasta grubunda mortalite \%23,5 (4 hasta) idi ve bu istatiksel olarak BISAP skoru $<3$ olan (0 hasta) hasta grubundan daha yüksekti $(\mathrm{p}=0.019)$. BİSAP skoru $<3$ olan hastaların ortalama hastanede kalma süreleri $7.58 \pm 4.04$ gündü ve BİSAP skoru $\geq 3$ olan hastalarda ise $15.35 \pm 1.66$ gündü $(\mathrm{p}=0.02)$.

Sonuç: Akut pankreatitte şiddet için doktor tutum endeksi (BİSAP) skoru, kabül esnasında mortaliteyi, morbiditeyi ve hastanede kalma süresini tahmin etmede harika bir skordur ve bu yüzden akut pankreatit ile kabul edilen hastaların yönetim protokolünü için de kullanışlıdır.

Anahtar Kelimeler: Abdominal Distensiyon, Akut Pankreatit, Doktor Tutum Endeksi, Organ Yetmezliği.

\section{ABSTRACT}

Objective: To investigate the role of Bedside index for severity of acute pancreatitis (BISAP) score in predicting the outcome of acute pancreatitis.

Methods: This single hospital based prospective study included fifty patients of acute pancreatitis admitted within 48 hours of onset of symptoms, who were divided into two groups ac- cording to admission BISAP score. BISAP score $<3$ (mild acute pancreatitis) and BISAP score >3 (severe acute pancreatitis). The ability of BISAP score to predict mortality, morbidity and hospital stay in acute pancreatitis patients was analyzed.

Results: A BISAP score of $>3$ was associated with increased risk of development of transient organ failure, persistent organ failure and pancreatic necrosis (Statistically significant). Mortality in group with BISAP $>3$ was $23.5 \%$ (4 patients) which was statistically higher than group with BISAP score $<3$ (0 patients) $(\mathrm{p}=0.019)$. The mean duration of hospital stay of patients in group with BISAP score $<3$ was $7.58 \pm 4.04$ days and in group with BISAP score $>3$ was $15.35 \pm$ 1.66. $(\mathrm{p}=0.02)$.

Conclusion: Bedside index for severity in acute pancreatitis (BISAP) score, at admission is an excellent score in predicting the mortality, morbidity and hospital stay and hence manage- ment protocol in patients admitted with acute pancreatitis. failure

Key words: Abdominal distension, acute pancreatitis, Bedside index, Organ 
Acute pancreatitis (AP) is defined as an inflammatory process of pancreas with peripancreatic tissue and multiple organ involvement inducing multi-organ dysfunction syndrome (MODs) with an increased mortality rate $(1,2)$.

Worldwide, gallstones are the most common cause of AP, accounting for approximately $45 \%$ of cases, alcohol being the second most common, accounting for $35 \%$ of cases (3). Other causes of AP include various drugs, trauma (accidental or iatrogenic), endoscopic retrograde cholangiopancreatography, metabolic abnormalities (hypertriglyceridemia, hypercalcemia), obstruction (tumors, pancreas divisum), infections (viral, parasitic, bacterial), and vascular abnormalities (emboli, ischemia, vasculitis). Hereditary forms of AP is caused by a mutation in the trypsinogen-1 gene allowing premature activation of trypsinogen to trypsin (4). Finally, about $10 \%$ of the cases of AP are idiopathic with no identifiable etiology (3).

In the majority of cases, AP is a mild selflimiting disease with a mortality of less than $2 \%$ (2). However despite considerable improvements in the treatment, mortality remains between $15 \%$ and $25 \%$ (2) in severe cases. If pancreatic necrosis is infected, mortality rate increases to $40 \%$ (5).

An improved outcome in the severe form of acute pancreatitis is based on early identification of disease severity and subsequent focused management of these high-risk patients. The clinician is poor at predicting the severity of AP on admission, and fails to identify up to two-thirds of patients, who eventually develop complications or die. The prognostic methods available to identify the severe cases are generally considered to be unsatisfactory or too cumbersome $(6,7)$. Rapid severity assessment remains a challenge and an obvious clinical need exists for a simple test that can identify patients at risk of developing severe acute pancreatitis. Multiple risk stratification tools of acute pancreatitis have been developed, but their clinical usefulness is limited. Older measures such as Ranson's criteria and modified Glasgow score use data that are not routinely collected at the time of hospitalization. In addition both requires 48 hours, thereby missing, and potentially reliable early therapeutic window $(8,9)$.

For this purpose a simple and accurate clinical scoring system that is bedside index for severity in acute pancreatitis (BISAP) scoring system was developed (10).This scoring system is used for stratifying patients according to their risk of hospital mortality. This scoring system enables us to identify patients at increased risk of mortality prior to the onset of organ failure. More ever data for BISAP score is collected within the first 24 hours of hospitalization. The ability to stratify patients early in their course is a major step for improving future management strategies in acute pancreatitis. It is an uncomplicated, quick and reasonably reliable method for assessment of disease severity on admission (11).

\section{BISAP Score includes:}

1. Blood urea nitrogen $>25 \mathrm{mg} / \mathrm{dl}$

2. Impaired mental status (Glasgow coma scale score $<15$ )

3. Systemic inflammatory response syndrome (SIRS).

SIRS is defined as Presence of two or more of the following criteria:

a. Pulse $>90 \mathrm{bpm}$

b. Respiration $>20 / \mathrm{min}$ or $\mathrm{PaCO}_{2}<32 \mathrm{mmHg}$

c. Temperature $>38$ or $<36^{\circ} \mathrm{C}$

d. WBC count $>12000$ cells $/ \mathrm{mm}^{3}$ or $<4000$ cells $/ \mathrm{mm}^{3}$ or $>10 \%$ immature bands.

4. Age $>60$ years.

5. Pleural effusion, detected on imaging (chest X-ray or USG or CT scan).

Each point on BISAP score is worth one point within 24 hours of presentation there is steady increase in risk for mortality with the increasing number of points. BISAP score is used to predict the mortality in patients with acute pancreatitis. BISAP score $\leq 2$ indicates mild acute pancreatitis and BISAP score $\geq 3$ severe indicates acute pancreatitis. A score of $0-2$ is associated with low mortality of $<2 \%$ and a score of $3-5$ is associated with a higher mortality of more than 15 $\%(10)$.

Objective: This study was aimed with following objective:

To investigate the role of Bedside index for severity of acute pancreatitis (BISAP) score in predicting the outcome of acute pancreatitis

\section{METHODS}

This present study was conducted in the Postgraduate Department of General Surgery, Government Medical College, Srinagar, in collaboration with the Department of Biochemistry 
over a period of $2 \frac{1}{2}$ years from June 2013 to Dec 2015.The study was a single hospital based and prospective one which included Fifty patients of acute pancreatitis who were admitted within 48 hours of onset of symptoms and diagnosed on the basis of clinical picture, biochemical profile, ultrasound examination of abdomen and sometimes computerized tomography of abdomen when required. These Fifty patients were divided into two groups according to admission BISAP score. BISAP score $\leq 2$ (mild acute pancreatitis) and BISAP score $\geq 3$ (severe acute pancreatitis). The ability of BISAP score to predict mortality, morbidity and hospital stay in acute pancreatitis patients was analyzed.

All these patients were subjected to detailed history and clinical examination and laboratory investigations.

Clinical History: Pain, radiation, duration and associated symptoms like nausea, vomiting, loss of appetite, jaundice, fever, and abdominal distension were noted. Personal history with particular reference to alcohol intake, drug intake were taken into account. Relevant family history was also asked.

Examination: Vital signs, hemodynamic stability, abdominal tenderness, guarding, abdominal distension, epigastric fullness, presence of free fluid and bowel sounds were recorded. Cardiovascular system status respiratory status and urine output of the patient were also observed.

Investigations: In each patient routine investigations like hemoglobin, WBC count, bleeding time, clotting time were carried out. Biochemical investigations like kidney function test (KFT), liver function test (LFT). Serum sodium, potassium, calcium $\left(\mathrm{ca}^{++}\right)$, phosphate, serum triglycerides levels, blood sugar, lactate dehydrogenase (LDH), serum amylase and serum lipase were performed.

Radiological investigations: Abdominopelvic ultrasonography, thorax and chest plain graphy were performed at admission. Contrast enhanced computerized tomography abdomen was done after 72 hours of admission when it is optimum to rule out pancreatic necrosis and properly delineate areas of necrosis.

The patients were managed on the standardized protocols of; severe acute pancreatitis in ICU setting which included keeping the patient nil per oral, Ryles tube suction, administration of intravenous (IV) fluids titrated according to urine output, prophylactic IV antibiotics, IV anti-spasmodics, IV analgesics. Prophylactic antibiotics were used for 7-14days, H-receptor antagonists or proton pump inhibitors were given for 7 days. If necessary respiratory support was given. During hospitalization microbiological tests of sputum, urine, faeces, or blood were performed, when the following susceptible clinical symptoms or signs appeared: body temperature $\geq 38.5$ and white blood cell (WBC) count $\geq 20000 /$, signs of peritoneal irritation (area) in more than two quadrants of abdomen and intractable malnutrition.

The sex, age, etiology, admission biochemical parameters and incidence of complications including acute respiratory distress syndrome (ARDS), renal failure, shock, encephalopathy, MODS local complications, hospital stay and mortality were observed by single investigator. Organ failure was defined as a score of $\geq 2$ in one or more of the three (respiratory, renal and cardiovascular) out of the five organ systems initially described in the Marshall score (12). Organ failure scores were calculated for all patients during the first $72 \mathrm{~h}$ of hospitalization. Duration of organ failure was defined as transient ( $\leq 48$ hours) or persistent $(>48$ hours) from the time of presentation.

\section{RESULTS}

There were 50 patients in the study 29 (58\%) males and $21(42 \%)$ females. The average age of male patients was $47.71 \pm 12.34$ years and of female patients was $51.48 \pm 12.77$ years. Etiology for acute pancreatitis was established as in Table 1. Most common etiological factor was found to be gall stones ( 25 patients, $50 \%$ ). Various symptomatogy is mentioned in table 2 .

Table 1: Etiology of acute pancreatitis.

\begin{tabular}{|l|l|}
\hline Etiology & No. of Patients (percentage) \\
\hline Gallstones & $25(50 \%)$ \\
\hline Biliary ascariasis & $12(24 \%)$ \\
\hline Idiopathic & $8(16 \%)$ \\
\hline Hyperlipidemia & $2(4 \%)$ \\
\hline Alcohol & $2(4 \%)$ \\
\hline Drug induced & $1(2 \%)$ \\
\hline Traumatic & 0 \\
\hline
\end{tabular}


Table 2: Clinical presentation.

\begin{tabular}{|l|l|}
\hline Symptoms & No. of patients \\
\hline Abdominal pain & 50 \\
\hline Nausea & 38 \\
\hline Vomiting & 37 \\
\hline Abdominal distension & 10 \\
\hline Fever & 6 \\
\hline Constipation & 3 \\
\hline Breathlessness & 1 \\
\hline Pedal edema & 1 \\
\hline
\end{tabular}

The sonographic findings at presentation regarding the assessment of pancreas are tabulated and presented as in Table 3 . In $32 \%$ of our patients the pancreas was not visualized initially because of overlying bowel gas shadows.

Table 3: Sonographic findings.

\begin{tabular}{|l|l|}
\hline USG findings & $\begin{array}{l}\text { No. of patients } \\
\text { (percentage) }\end{array}$ \\
\hline Diffuse edematous pancreas & $28(56 \%)$ \\
\hline Pancreas not visualized & $16(32 \%)$ \\
\hline Focal pancreatic edema & $6(12 \%)$ \\
\hline
\end{tabular}

MORBIDITY: With regard to morbidity, out of 50 patients, $10(20 \%)$ developed organ failure. Out of 10 patients $7(78.8 \%)$ patients had transient organ failure and $3(22.2 \%)$ had persistent organ failure. Among 7 patients with transient organ failure 6 were having BISAP score of $\geq 3$ and one was having BISAP score of $<3$. While as $11(25.6 \%)$ patients with BISAP score $\geq 3$ and 32 (74.4\%) with BISAP score of $<3$ did not develop transient organ failure, which is statistically highly significant $(\mathrm{p}=0.002)$. All the 3 patients who developed persistent organ failure were having BISAP score $\geq 3.14(29.8 \%)$ patients with BISAP score $\geq 3$ and 33 (70.2\%) patients with BISAP score $<3$ did not develop persistent organ failure, which is statistically significant $(\mathrm{p}=0.013$ ). Most common organ failure was ARDS. 13 patients $(26 \%)$ de- veloped pancreatic necrosis, out of which 8 had BISAP score $\geq 3(47 \%)$ and 5 had BISAP score $<3$ (15\%) (Table 4 and Table 5).

Table 4: Pattern of organ failure (p-value $=0.001$ ).

\begin{tabular}{|c|c|c|c|}
\hline \multirow{2}{*}{ Organ failure } & \multicolumn{2}{|c|}{$\begin{array}{l}\text { Number of } \\
\text { patients(percentage) }\end{array}$} & \multirow{2}{*}{$\begin{array}{l}\text { Total } \\
\text { (percentage) }\end{array}$} \\
\hline & $\begin{array}{l}\text { BISAP } \\
\text { score } \geq 3\end{array}$ & $\begin{array}{l}\text { BISAP } \\
\text { score }<3\end{array}$ & \\
\hline $\begin{array}{l}\text { Acute respiratory } \\
\text { distress syndrome } \\
\text { (ARDS) }\end{array}$ & $5(10 \%)$ & 0 & $5(10 \%)$ \\
\hline Renal & $2(4 \%)$ & $1(2 \%)$ & $3(6 \%)$ \\
\hline Cardiac & $1(2 \%)$ & 0 & $1(2 \%)$ \\
\hline $\begin{array}{l}\text { Multiple organ } \\
\text { dysfunction } \\
\text { syndrome (MODS) }\end{array}$ & $1(2 \%)$ & 0 & $1(2 \%)$ \\
\hline No & $8(16 \%)$ & $32(64 \%)$ & $40(80 \%)$ \\
\hline Total & $17(34 \%)$ & $33(66 \%)$ & $50(100 \%)$ \\
\hline
\end{tabular}

Pancreatic necrosis was observed in 8 (16\%) patients out of $17(34 \%)$ with BISAP Score $\geq 3$,while it was seen in $5(10 \%)$ out of $33(66 \%)$ with BISAP Score $<3$, which is statistically significant $(\mathrm{p}=0.015)$. The mean duration of hospital stay of patients in group with BISAP score $<3$ was $7.58 \pm 4.04$ days and in group with BISAP score $\geq 3$ was $15.35 \pm 1.66$. $(\mathrm{p}=0.02)$.

Mortality: The overall mortality in our study was $8 \%$ (4 patients). Mortality in group with BISAP $\geq 3$ was $23.5 \%$ ( 4 patients) which was statistically higher than group with BISAP score $<3$ (0 patients) $(\mathrm{p}=0.019)$

\section{DISCUSSION}

Acute pancreatitis (AP) remains a serious disease. It is defined as an inflammatory process of the pancreas with possible peripancreatic tissue and multi-organ involvement inducing multi-organ dysfunction syndrome (mods) with an increased mortality rate. The majority of patients present with a mild disease, however approximately $20 \%$ develop a severe course and require appropriate management in an intensive care unit (1). According to the Atlanta classification, severe acute pancreatitis (SAP) is defined as an AP associated with local and/or systemic complications (2).

Multi-organ dysfunction syndrome, the extent of pancreatic necrosis, infection and sepsis 
Doi: $10.16899 /$ ctd. 76758

Table 5: Transient and Persistent organ failure.

\begin{tabular}{|c|c|c|c|c|c|c|c|}
\hline \multirow{2}{*}{$\begin{array}{l}\text { Transient } \\
\text { organ } \\
\text { failure }\end{array}$} & \multicolumn{2}{|c|}{ Number of patients(percentage) } & \multirow{2}{*}{$\begin{array}{l}\text { Total } \\
\text { (percentage) }\end{array}$} & \multirow{2}{*}{$\begin{array}{l}\text { Persistent } \\
\text { organ failure }\end{array}$} & \multicolumn{2}{|c|}{ Number of patients(percentage) } & \multirow{2}{*}{$\begin{array}{l}\text { Total } \\
\text { (percentage) }\end{array}$} \\
\hline & $\begin{array}{l}\text { BISAP SCORE } \\
\geq 3\end{array}$ & $\begin{array}{l}\text { BISAP SCORE } \\
<3\end{array}$ & & & $\begin{array}{l}\text { BISAP } \\
\text { SCORE } \geq 3\end{array}$ & $\begin{array}{l}\text { BISAP } \\
\text { SCORE <3 }\end{array}$ & \\
\hline Yes & $6(12 \%)$ & $1(2 \%)$ & $7(14 \%)$ & Yes & $3(6 \%)$ & 0 & $3(6 \%)$ \\
\hline No & $11(22 \%)$ & $32(64 \%)$ & $43(86 \%)$ & No & $14(28 \%)$ & $33(66 \%)$ & $47(94 \%)$ \\
\hline Total & $20(40)$ & $30(60 \%)$ & $50(100 \%)$ & Total & $17(34 \%)$ & $33(66 \%)$ & $50(100 \%)$ \\
\hline p-value & 0.002 & & & P-value & 0.013 & & \\
\hline
\end{tabular}

are the major determinants of mortality in AP (4). Pancreatic necrosis is considered as a potential risk for infection, which represents the primary cause of late mortality.

Occurrence of acute respiratory failure (ARF), cardiovascular failure (CVF) and renal failure (RF) can predict the fatal outcome in SAP (13). A wide range of mortality $(20 \%-60 \%)$ has been reported in SAP (14). Early diagnosis and prognostic evaluation are extremely important and may reduce the morbidity and mortality. On account of differences in outcome between patients with mild and severe disease, it is important to define that group of patients who will develop severe pancreatitis, which still represents challenge for the clinician. Interestingly, when seeking medical attention (usually 12 to 24 hours after the onset of pain) most patients do not exhibit multiple organ dysfunction, which is likely to emerge by the second or third day.

Identification of patients at risk for mortality early in the course of acute pancreatitis is an important step in improving outcome. Multiple risk stratification tools for acute pancreatitis have been developed, but their clinical usefulness is limited. Older measures such as, the Ranson's criteria and modified Glasgow score use data that are not routinely collected at the time of hospitalization. In addition, both require 48 hours, thereby missing potentially valuable early therapeutic window (10) The APACHE II score is the most widely used prediction system currently but it requires the collection of large number of parameters, some of which may not be relevant to prognosis $(4,5)$.

For this purpose a simple and accurate clinical scoring system that is bedside index for severity in acute pancreatitis (BISAP) scoring system (13) was developed. This scoring system used for stratifying patients according to their risk of hospital mortality and is able to identify patients at increased risk of mortality prior to the onset of organ failure. Data for BISAP score is being collected within the first $24 \mathrm{hr}$ of hospitalization (9). The ability to stratify patients early in their course is a major step to improve management strategies in acute pancreatitis.

The severity of acute pancreatitis was defined on the basis of BISAP score. In our study out of 50 patients, 17 (34\%) had severe pancreatitis that is they had BISAP score more than or equal to 3 and $33(66 \%)$ were classified as having mild pancreatitis having BISAP score of less than 3 . Majority of patients with mild form of disease, the course was self-limiting. While in severe pancreatitis with BISAP score 3 or more morbidity, mortality and hospital stay was significantly higher.

\section{CONCLUSION:}

Bedside index for severity in acute pancreatitis (BISAP) score, at admission is an excellent score in predicting the mortality, morbidity and hospital stay and hence management protocol in patients admitted with acute pancreatitis. 


\section{REFERENCES}

1. Edward L, Bradley III MD. A clinically based classification system of acute pancreatitis. Summary of international symposium on acute pancreatitis. Arch Surg 1993;128:586-590

2. Symmers WSC. Acute alcoholic pancreatitis. Dublin J Med Sci 1917;143:244-247.

3. Clavein PA, Burgan S and Moossa AR. Serum enzymes and other laboratory tests in acute pancreatitis.Br J Surg. 1989;76(12):1234-43.

4. Beger HG, Isenmann R. Surgical management of necrotizing pancreatitis. SurgClin North Am 1999; 74(4):783-800.

5. Ranson JH, Rifkind KM. Prognostic signs and the role of operative management in acute pancreatitis. SurgGynecolObstet 1974;139:69-81.

6. Knaus WA, Draper EA, Wagner DP et al. APACHE II: a severity of disease classification system. Crit Care Med 1985; 13:818-82.

7. Uhl W, Warshaw A, Imrie $\mathrm{C}$ et al. International association of pancreatology guidelines for the surgical management of acute pancreatitis. Pancreatology 2002;2:565-573.

8. Wilson C, Heath DI, Imrie CW. Prediction of outcome in acute pancreatitis: A comparative study of
APACHE II, Clinical assessment and multiple factor scoring systems. Br J Surg 1990;77:1260-4.

9. Issenmann R, Rau B. Does Atlanta classification of severe acute pancreatits really correlate with outcome in patients with pancreatic necrosis? Gastroenterology Suppl 2001;120:A-485.

10. Ranson JH, Rifkind KM. Prognostic signs and the role of operative management in acute pancreatitis. Surg Gynecol Obstet 1974;139: 6981.

11. Khan AA, Parikh D. Improved prediction of outcome in patients with severe acute pancreatitis by APACHE II score at 48 hours after hospital admission compared with APACHE II score at admission. Arch Surg. 2002;137:1136-1140.

12. Balthazar EJ, Robinson DL, Megibow AJ et al. Acute pancreatitis: Value of computerized tomography in establishing prognosis. Radiology. 1990; 174:331-336.

13. Larvin M, McMohan MJ. APACHE-II score for assessment and monitoring of AP. Lancet 1989; 2: 201-5.

14. Wu BU, Johannes RS, Sun et al. Early prediction of mortality in Acute pancreatitis: A large population based study. Gut 2008;57:1648-703. 